Şırnak Üniversitesi

Ilahiyat Fakültesi Dergisi

Sayı 26 Haziran 2021

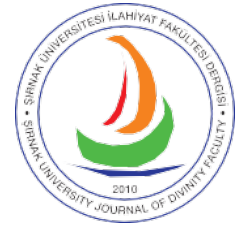

e-ISSN 2667-6575
Şırnak University

Journal of Divinity Faculty

Issue 26 June 2021

\title{
Ahmed b. Hanbel Müsnedi'nde İç Düzen Problemi
}

The Internal Layout Problem in Ahmad b. Hanbal's Musnad

\section{Ahmed ÜRKMEZ}

Doç. Dr., Pamukkale Üniversitesi, İlahiyat Fakültesi, Hadis Ana Bilim Dalı Associate Professor, Pamukkale University, Faculty of Divinity, Department of Hadith

Denizli, Turkey aurkmez@pau.edu.tr https://orcid.org/0000-0002-6594-7997

\section{Makale Bilgisi / Article Information}

Makale Türü / Article Types: Araştırma Makalesi / Research Article

Geliş Tarihi / Received: 5 Ocak / January 2021

Kabul Tarihi / Accepted: 11 Mart / March 2021

Yayın Tarihi / Published: 15 Haziran / June 2021

Say1 / Issue: 26 Sayfa / Pages: 5-24

Atıf / Cite as: Ürkmez, Ahmed. "Ahmed b. Hanbel Müsnedi'nde İç Düzen Problemi [The Internal Layout Problem in Ahmad b. Hanbal's Musnad]". Şırnak Üniversitesi İlahiyat Fakültesi Dergisi - Şırnak University Journal of Divinity Faculty 26 (June 2021), 5-24. https://doi.org/10.35415/sirnakifd.854320

Etik Beyanı / Ethics Declaration: Bu makalede bilimsel araştırma ve yayın etiği ilkelerine riayet edilmiştir. Makale etik izin gerektirmeyen bir çalışma olup en az iki hakem tarafından incelenmiş ve intihal içermediği teyit edilmiştir. / In this article, the principles of scientific research and publication ethics are respected. The article is a study that does not require ethical permission. It has been reviewed by at least two referees and was confirmed that it did not contain plagiarism.

Copyright @ P Published by Şırnak Üniversitesi, İlahiyat Fakültesi / Şırnak, Türkiye (Şırnak University, Faculty of Divinity, Şırnak, 73000 Turkey). 


\section{Özet}

Müsnedler hadis tarihinde belirleyici konumu olan kapsamlı ve özgün eserlerdir. Bir tasnif tarzı olarak müsnedin, hadislerin konusuna veya sıhhatine dayalı bir bölümleme içermediği bilinmektedir. Senedin sonunda yer alan sahabi ravinin esas alındığı ve her bir isim için ayrılan bölümde o ismin rivayetlerine topluca yer verildiği görülmektedir. Bu bağlamda, sahabilerin kendi içinde sıralanmasında alfabetik diziliş gözetilmemekte olup, önce fazilete dayalı, ardından bölgelere göre bir dağılım ile karşılaşılmaktadır. Ahmed b. Hanbel'in Müsned'ini yazdıktan sonra dönemin sosyal ve politik şartlarından ötürü düzenli olarak okutmaya ve tashih etmeye fırsat bulamadığı bilinmektedir. Eserin ana ravisi konumundaki oğlu Abdullah'ın çalışmaları ve ziyadeleri de metnin tam bir düzene kavuşmasını sağlayamamıştır. Yapılan araştırmalar ve eseri tahkik edenlerin ifadeleri, başta bir sahabinin hadislerinin birden fazla yerde zikredilmesi ve herhangi bir ek yarar olmaksızın bir rivayetin senediyle ve metniyle aynen tekrar edilmesi olmak üzere, iç düzensizlikten kaynaklanan birden fazla sorunu ortaya koymaktadır. Farklı bölgelere mensup sahabilerin hadislerinin birbiriyle karışık hâlde sunulması da bu listeye eklenebilir. Makalenin giriş kısmında bu ve benzeri meselelere değinildikten sonra, başlıktaki konu iki alt başlıkta irdelenmiştir: İç düzen/düzensizlik ve mükerrer rivayetler. İlk başlıkta, Ahmed b. Hanbel'in eserindeki müsnedlerin hacme veya isme göre tasnifinde yaşanan kimi aksamalara dikkat çekilmiş ve 31. cildin muhtevası örnek olarak sunulmuştur. Yine bu ilk bölümde, başta eseri tahkik edenler olmak üzere müsned hakkında daha önce çalışanların tespitlerine yer verilmiştir. Ayrıca parçalı müsned kavramı üzerinde durulmuş ve eserde ismi verilen 745 sahabiye ait müsnedler "standart olanlar" ve "parçalı olanlar" şeklinde ikiye ayrılarak incelenmiştir. Standart müsnedlerden kasıt, adına bir defa başlık açlıp bütün hadisleri tek bir yerde nakledilen sahabilere ait müsnedlerdir. Parçalı müsned ise bir sahabinin müsnedinin birden fazla parçaya bölünmesi ve her bir parçanın farklı bir ciltte konumlandırılmasıdır. Genel olarak bakıldığında, eserdeki müsnedlerden üçte ikisinin standart yapıda olduğu, parçalı müsnedlerin büyük bölümünün ise iki parçaya ayrılmış örneklerden oluştuğu ifade edilebilir. İncelemeye dair detaylı rakamsal veriler tablolar hâlinde sunulmuş ve yorumlanmıştır. Müsnedleri iki parçadan oluşan sahabiler bu araştırma kapsamında üç ana kategoriye ayrılmıştır. Toplam rivayet sayısı 50'nin üzerinde olanlar birinci kategoride (K1) ele alınmıştır. Ebü'd-Derdâ, Zeyd b. Hâlid el-Cühenî ve Adiy b. Hâtim gibi sahabiler bu bağlamda zikredilebilir. İkinci kategoride (K2) ise rivayet sayısı 10-50 arasında olanlar yer almaktadır. Tespit edilen isimlerden seçilen ve Ukbe ibnü'l-Hâris, Amr ibnü'l-Âs ve Ammâr b. Yâsir'in de içinde bulunduğu 15 maddelik bir liste bu kategoriye örnek olarak sunulmuştur. Bu noktada dikkat çeken bir diğer husus, tespit edilen 100'ü aşkın örnekte, toplam hadis sayısı 10' dan az olan sahabilere ait müsnedlerin ikiye bölünerek verilmiş olmasıdır. Itbân b. Mâlik, Zeynep bint Cahş ve Ümmü Harâm bint Milhân'ın da aralarında bulunduğu on sahabiden müteşekkil bir tabloya bu boyuta örnek olarak yer verilmiştir. Makale çerçevesinde yer alan ve üçüncü kategori (K3) olarak adlandırılan bu kategoriye ilave edilebilecek 40'a yakın örnekte ise, bir sahabinin Müsned'de sadece iki rivayeti olduğu hâlde müsnedi iki parça şeklinde ve $(1+1)$ düzeninde sunulmuştur. Mükerrer rivayetler başlıklı ikinci bölümde ise öncelikle Müsned'deki tekrar oranlarına dair genel veriler paylaşılmıştır. Müsned'in üçte ikisinden fazlasının tekrarlardan oluştuğu, gerek tarafımızdan yapılan incelemelerde, gerekse diğer araştırmacıların çalışmalarında tespit edilmiş bir gerçekliktir. Ayrıca bu bölümde, parçalı müsnedlerle tekrar olgusu arasındaki ilişki de ele alınmıştır. (1+1) müsned yapıları özelindeki inceleme, ikinci parçada verilen hadisin çok büyük oranda birinci parçada verilen hadisin isnad ve metin bakımından tekrarı olduğunu ortaya koymuştur. Araştırmada ulaşılan bir diğer bulgu ise hadis sayısı daha az olan sahabilerin rivayetlerine ait mükerrerlerde sened ve metin bakımından aynen tekrar edilme oranının diğerlerine göre daha yüksek olduğudur.

Anahtar Kelimeler: Hadis, Sünnet, Müsned, Ahmed b. Hanbel, Mükerrer Rivayetler. 


\section{Summary}

Musnads are comprehensive and original works that have a decisive position in hadith history. As a classification style, musnad does not categorize the hadiths according to their subject or soundness. It is seen that the sahabi narrator at the end of the isnad is taken as the basis and that the narrations of that name are included collectively in the section reserved for each name. In this context, the alphabetical order is ignored in ordering the sahaba within themselves and a distribution is made, first, according to the virtue of the narrator, and then by their regions. The subject in the title is examined under two sub-headings: Internal order/disorder and repeated narrations. In this first section, the determinations of those who previously studied the work are included. In addition, the concept of fragmented musnad was emphasized and the musnads belonging to 745 sahaba named in the work were divided into two as "the standard ones" and "the fragmented ones". The standard musnads are musnads belonging to the sahaba whose hadiths were mentioned once, and all hadiths were recorded in one place. And the fragmented musnad is the division of a sahabi's musnad into more than one piece and each part is positioned in a different volume. In general, it can be stated that two-thirds of the works in the book are in standard structure, and most of the fragmented musnads consist of two-part samples. Detailed numerical data regarding the analysis were presented in tables and interpreted. Sahaba whose musnads consist of two parts are divided into three main categories within the scope of this research. Those whose total number of narrations is over 50 are considered in the first category (K1). Sahaba like Abu Darda, Zayd b. Khalid al-Juhani and Adi b. Hatim can be mentioned in this context. In the second category (K2), there are those who have between 10-50 narrations. A list of 15 items including Ukbah $b$. al-Harith, Amr b. al-As, and Ammar b. Yasir is presented as an example for this category. Another point that draws attention at this point is that in more than 100 examples determined, musnads belonging to the sahaba, whose total number of hadiths are less than 10 , were divided into two. A table consisting of ten sahaba including Utban b. Malik, Zaynab bint Jahsh and Umm Haram bint Milhan is given as an example of this dimension. This third category (K3) within the framework of the article includes nearly 40 examples of sahaba who two narrations in Musnad have only, which are presented in two parts and (1+1) order. In the second chapter titled repeated narrations, general data on the repetition rates in Musnad are primarily shared. It is a reality that more than two-thirds of Musnad consists of repetitions, which has been determined both in my investigations and in the studies of other researchers. In addition, the relationship between fragmented musnads and repetition phenomena is also discussed in this section. The examination of the $(1+1)$ musnad structures reveals that the hadith given in the second part is mostly a repetition of the hadith given in the first part in terms of isnad and text. Another finding of the study is that the rate of exact repetition in terms of isnad and text of the narrations of the sahaba with a lower number of hadiths is higher than the others.

Keywords: Hadith, Sunnah, Musnad, Ahmad b. Hanbal, Repeated Narrations. 


\section{Giriş}

Müsned, Hadis ilminin birden fazla anlamda kullanılan gözde kavramlarından birisidir. Kelime karşılığından hareket edildiğinde “bir sözlü kaynağa dayandırılan isnadlı tüm verileri" ifade edecek kadar geniş bir kapsama alanına sahip görünse de ${ }^{1}$ istılahtaki kullanımı "senedi kesintisiz biçimde muttasıl olan hadis", "herkesin itimad ettiği güvenilir âlim” 2 şeklinde ve daha sınırlıdır. Hadis çeşitlerinden bahsedilirken merfû hadislere müsned denilebilmekte ${ }^{3}$, tasnif türleri bağlamında ise müsned, ravi isimlerini esas alan (ale'r-ricâl) bir hadis tasnif yöntemini ifade etmektedir. Bu yöntemin ayırt edici özelliği, her bir sahabi raviden gelen rivayetlerin o sahabinin ismi altında toplanması ve konuya yahut sıhhate dayalı ilave bir ayrıma gidilmemesidir.

Ahmed b. Hanbel'in (öl.241/855), türünün en tanınan örneği konumundaki Müsned çalışması, başta ravileri, tenkide uğrayan rivayetleri, içerdiği konular ve kullandığı yöntemler olmak üzere hakkında oldukça fazla araştırma, tez ve kitap çalışması yapılmış4 klasik bir Hadis mecmuasıdır. Uzun yıllar altı ciltlik bir baskısıyla mütedavil olan eser, on yıl boyunca süren ve 2010 yılında tamamlanan büyük bir projeyle Muhakkik Şuayb Arnavut ve ekibi tarafından ilim âleminin istifadesine sunulmuştur. Yeni baskının gün yüzüne çıkmasını müteakip tarafımızdan yapılan bir seçki çalışmasıyla da eserdeki merfû, kavli ve sahih olma özelliklerinin üçünü de taşıyan ve tekrar içermeyen 1010 hadis bir kitap hâlinde bir araya getirilmiştir. $^{5}$

1 Ebû Nasr İsmail b. Hammâd el-Cevherî, es-Sthâh (Kahire: Dâru'l-Hadîs, 2009), 563; Cemâlüddîn Muhammed b. Mükerrem İbn Manzûr, Lisânü'l-Arab (Riyad: Vizâratü'ş-Şüûni'l-İslâmiyye, ts.), 4/205-206.

2 Abdullah Aydınlı, Hadis Istılahları Sözlü̈̆̈̈ (İstanbul: İFAV, 2009), 219 vd.; Ahmed Naim, Sahîh-i Buhârî Muhtasarı Tecrîd-i Sarîh Tercemesi (Ankara: Başbakanlık Basımevi, 1976), 1/71-73; Mücteba Uğur, Ansiklopedik Hadis Terimleri Sözlüğü (Ankara: TDV Yayınları, 1992), 281-282.

3 Ebü'l-Fidâ İsmail İ̉n Kesîr, İhtisâru Ulûmi'l-Hadîs (Beyrut: Dâru'l-Kütübi'l-i̇lmiyye, 1989), 34; Ebû Amr Ömer b. Abdurrahmân İbnü's-Salâh, Ulûmü'l-Hadîs (Beyrut: Dâru'l-Fikr, 1986), 42-43; Celâlüddîn Abdurrahmân b. Ebî Bekr es-Suyûtî, Tedrîbü'r-Râvî fî Şerhi Takrîbi'n-Nevâvî (Beyrut: Dâru'l-Kitâbi'1-Arabî, 1993), 1/147-148.

4 Ebû Abdullah Ahmed b. Hanbel, el-Müsned (Beyrut: Müessesetü'r-Risâle, 1999), 1/82-91 (muhakkikin mukaddimesi); Hayati Ak, “Türkiye'de Müsnedler Üzerine Yapılan Çalışmalarla İlgili Bibliyografik Bir İnceleme", Rumeli İslâm Araştırmaları Dergisi 1/2 (2018), 66-80; Yaşar Kandemir, "el-Müsned", Türkiye Diyanet Vakfi İslâm Ansiklopedisi (İstanbul: TDV Yayınları, 2006), 32/104-105.

5 Ahmed Ürkmez, Mülteka'l-Ashâbi'l-Emced fí İntikâi Mesânîdi Ahmed (Ankara: Diyanet İşleri Başkanlığı Yayınları, 2021). 


\section{1. İç Düzen/Düzensizlik}

Her ne kadar hadis ve sünneti tanımada müracaat edilen en temel kaynaklardan birisi olsa $\mathrm{da}^{6}$, Müsned' in son şekli verilememiş dağınık bir metin yapısı arz ettiği, öteden beri pek çok ilmi yazıda7 kayda geçirilmiş bir husustur. Eserin konulara göre (ale'l-ebvâb) tasnif edilmemiş olması, sıhhate dayalı bir ayrıma temelde gidilmemesi ve sahabi isimlerinin kendi içinde alfabetik olarak sıralanmaması, söz konusu dağınıklığa neden olan faktörler arasında ilk akla gelenlerdir. Ancak durumu bu teorik tercihlerden ziyade pratik yaşanmışlıklardan hareketle izah etmek daha makul bir seçenektir. Zira müellifin, simge isimlerinden birisi sayıldığı mihne ${ }^{8}$ atmosferinde ömrünün en verimli olması beklenen yıllarını başta hapis, darp, ev hapsi ve sürgün olmak üzere ağır fiziksel cezalar altında geçirdiği bilinmektedir. Bu dönemin düzenli öğrenci okutamadan, insan ve kitap kaynaklarına erişim sağlayamadan ve hatta yeterli yazı malzemesi bile tedarik edemeden ${ }^{9}$ geçirilmiş olması, bugüne ulaşan metnin değeri kadar başarı oranını da artırmaktadır. Normal şartlar altında kusur sayılabilecek tasnif hatalarının, musannifin maruz kaldığı olağanüstü hâl koşulları göz önüne alındığında mazur görülme ihtimali oldukça yüksektir. Yine bu süreçte eserin ana ravisi olarak yer alan oğul Abdullah'ın ve esere yaptı̆̆ı ziyadelerin literatürde önemli yer tutması da bundan kaynaklanıyor olmalıdır.

Ahmed b. Hanbel'in eserde benimsediği temel bir sıralamanın varlığı, Müsned'in içeriğinin sonraki nesillere belirli ölçüde derli toplu ulaşmasında olumlu rol oynamıştır. Fazilete dayalı görünen ve hanımların rivayetlerine de en sonda müstakil bir yer ayıran bu sıralama şöyledir:

Aşere-i Mübeşşere (Cennetle müjdelenen on sahabi),

Ehli Beyt (Resûlullah'ın -sav- aile çevresi);

Abâdile (Dört Abdullah): Abdullah b. Abbâs, Abdullah b. Mes'ûd, Abdullah b. Ömer, Abdullah b. Amr;

6 Ebû Musa el-Medînî, Hasâisu'l-Müsned (Kahire: Dâru'l-Hadîs, 1995), 24 vd.

7 Bekir Kuzudişli, “Müsnedleri Dışında Zikredilen Sahâbîler Bağlamında Ahmed b. Hanbel'in Müsned'i -Ebû Hüreyre Örneği-", Hadis Tetkikleri Dergisi 8/2 (2010), 70-71.

8 Ali Kaya, “Mihne Hadisesi ve Hadis İlmine Etkileri Bakımından Mihne'nin Sonuçları”, Cumhuriyet Üniversitesi İlâhiyat Fakültesi Dergisi 1/19 (2015), 7-32; Hayrettin Yücesoy, "Mihne”, Türkiye Diyanet Vakfı İslâm Ansiklopedisi, 2006, 30/26-28.

9 Şemsüddin İbnü'l-Cezerî, el-Mas'adü'l-Ahmed fî Hatmi Müsnedi'l-İmâm Ahmed (Kahire: Dâru'l-Hadîs, 1995), 35 vd. 
Müksirûn (Çok hadis rivayet edenler): Ebû Hüreyre, Ebû Sa'îd el-Hudrî, Enes b. Mâlik, Câbir b. Abdullah;

Beldeler: Mekkeliler (c.24-25), Medîneliler (c.26-27), Şamlılar (c.28-29), Kûfeliler (c.3032), Basralılar (c.33-34);

Ensâr Müsnedi (c.35-39), Hz. Âişe ve diğer hanım sahabiler (c.40-45).

Bu dizilişte özellikle beldelere göre yapılan ayrıma kadarki ilk bölümün, yani Câbir b. Abdullah müsnedinin bitimine kadar olan kısmın, kitabın geri kalanına nazaran çok daha düzenli olduğunu belirtmek gerekir. 15299 hadis ihtiva eden söz konusu ilk yarı, bu araştırmada esas alınan 50 ciltlik Şuayb Arnavut tahkikinin ilk 23 cildini teşkil etmekte olup, fihristlere ayrılan son beş cilt çıartıldığında, 27647 hadisi kapsayan eserin hacim olarak yarısından fazlasına tekabül etmektedir. Gerek şöhret gerekse rivayet bakımından hadis geleneğinin ağırlık merkezini oluşturan bu az sayıda ismin müsnedlerinin ciltlere dağılımı aşağıdaki tabloda gösterilmiştir:

Tablo 1: Sahabi Müsnedlerinin Ciltlere Dağılımı (İlk 23 Cilt)

\begin{tabular}{|c|l|}
\hline Cilt & Kapsadı̆̆ı Sahabi Müsnedleri \\
\hline 1 & Ebûbekir es-Sıddîk, Ömer ibnü'l-Hattâb, Osmân b. Affân \\
\hline 2 & Ali b. Ebî Tâlib \\
\hline $3 / 1$ & Aşere-i Mübeşşere ve Ehl-i Beyt Mensubu Diğer Erkek Sahabiler \\
\hline $3 / 2,4-5$ & Abdullah b. Abbâs \\
\hline $6-7$ & Abdullah b. Mes'ûd \\
\hline $8-10$ & Abdullah b. Ömer \\
\hline 11 & Abdullah b. Amr ve Ebû Ramse \\
\hline $12-16$ & Ebû Hüreyre \\
\hline $17-18$ & Ebû Sa'îd el-Hudrî \\
\hline $19-21$ & Enes b. Mâlik \\
\hline $22-23$ & Câbir b. Abdullah \\
\hline &
\end{tabular}

Bu tabloda düzenli bir dizilişi bozduğu görülen unsur, 11. cildin bitiminde Ebû Ramse adlı bir sahabiye ait toplam 15 hadisten (7104-7118) oluşan müsneddir. Abâdile ile müksirûn arasına sıkışmış ama iki bünyede de yer almayan bu bölüm, Müsned'in ikinci yarısında sıkça rastlanan ve sistematik akışı bozan tekil isimlerin durumuyla benzerlik göstermektedir. 
Üçüncü ciltte ise daha farklı bir durumdan bahsedilebilir. Yine eserin ikinci yarısında sıkça karşılaşılan dağınık sahabi müsnedi gruplarına benzer şekilde yirmiyi aşkın ismin müsnedi tek ciltte bir araya getirilmiştir. Ancak burada az sayıda hadis içeren söz konusu müsnedlerin sahiplerini birbirine bağlayan ve 24. ciltten itibaren rastlanamayan ortak bir payda söz konusudur. Nitekim önce “Aşere-i Mübeşşere Mensubu Diğer Sahabiler” olarak Talha b. Ubeydullâh, ez-Zübeyr ibnü'l-Avvâm, Sa'd b. Ebî Vakkâs, Sa'îd b. Zeyd, Abdurrahman b. Avf ve Ebû Ubeyde ibnü'l-Cerrâh'ın müsnedlerine yer verilmiştir. Ardından ise Hz. Peygamber' in (sav) amcası Hz. Abbâs ile amcaoğullarından Hz. Ali dışında kalan ve dolayısıyla "Ehl-i Beyt Mensubu Diğer Erkek Sahabiler" olarak nitelendirilebilecek isimler gelmiştir. Ehl-i Beyt ile Abâdile arasında geçişi sağlayan isim olarak Abdullah b. Abbâs'ın 1838-2089 numaralı hadisleri 3. ciltte iken, diğer hadisleri müteakip iki cilttedir.

Mekkelilerin hadisleriyle başlayan 24. cilt ve devamında ise özellikle hacim bakımından çeşitli dengesizlikler tespit edilmiştir. Hatta denilebilir ki, kitabın ilk yarısındaki düzeni andıran tek kesit, Übey b. Ka'b, Ebû Zer el-Ğıfârî ve Zeyd b. Sâbit müsnedlerini içeren 35. cilt ile Hz. Âişe müsnedini içeren 40-43. ciltlerdir. Diğer ciltlerde ise aşağıdaki örnekte görülen tarzda oldukça farklı bir muhtevayla karşılaşılmaktadır.

Tablo 2: Müsned'in Düzensiz Bölümlerine Bir Örnek Olarak 31. Cilt

\begin{tabular}{|c|l|}
\hline Cilt & Kapsadı̆̆ı Sahabi Müsnedleri \\
\hline 31 & $\begin{array}{l}\text { Parçalar (10 Kişi/30 hadis)-Ebû Cühayfe (30 hadis)-Parçalar (11 Kişi/23 hadis)- } \\
\text { Cündüb b. Abdullah el-Becelî (21 hadis)-Parçalar (5 Kişi/21 hadis)-Vâil b. Hucr (42 } \\
\text { hadis)-Ammâr b. Yâsir (15 hadis)-Parçalar (7 Kişi/12 hadis)-Misver b. Mahrame (24 } \\
\text { hadis)-Suheyb b. Sinân er-Rûmî (12 hadis)-Parçalar (27 Kişi/49 hadis)-Rifâ'a b. Râfi' } \\
\text { (6 hadis)-Parçalar (28 Kişi/44 hadis)-Hanzala el-Kâtib (5 hadis)-Parçalar (15 Kişi/55 } \\
\text { hadis)-Abdullah b. Ebî Evfâ (50 hadis)-Cerîr b. Abdullah (111 hadis). }\end{array}$ \\
\hline
\end{tabular}

Tabloda "Parçalar" ifadesiyle kastedilen, önemli bir bölümü mübhem ravilerin ve kendisinden tek hadis rivayet edilen isimlerin müsnedlerinin birleşiminden oluşan bölümlerdir. Normal müsned düzenini yansıtan derli toplu bölümlerin arasına, ortalama hadis sayısı ikiyi üçü geçmeyen kişilerden oluşan farklı hacimlerde rivayet grupları girmiş bulunmaktadır. 
Eserin ikinci yarısının diğer bölümlerinde de ilk yarıdaki müsnedlere ait olduğu halde burada nakledilen rivayetlerin olduğuna dair araştırma sonuçlar1 ${ }^{10}$ bulunduğu gibi, beldelere göre yapılan ayrımın hilafına rivayet yerleşimlere rastlandığına yönelik tespitler de mevcuttur. Nitekim muhakkik Şuayb Arnavut, tahkikinin mukaddimesinde duruma şu sözlerle işaret etmektedir:

“Müsned, daha ziyade müsveddeye benzeyen bu haliyle elimize ulaşmış, kitabın özüne dokunmayan pek çok yerinde de buna bağlı problemler oluşmuştur. Söz konusu problemlerden bazıları şöyledir: Müksirûna ait hadislerden bir kısmının müsnedleri dışında rivayet edilmesi, tek bir hadisin ilave bir yarar olmaksızın senediyle ve metniyle tekrar edilmesi, tek bir sahabinin hadislerinin Müsned'in birden fazla yerinde ayrı ayrı verilmesi, Şamlılarla Medinelilerin hadislerinin karıştırılması, Kûfelilerle Basralıların hadislerinin ayrılmaması, erkeklerin hadislerinden bazılarının kadınların hadislerine katılması, kabile müsnedlerinin yerleşim merkezinde yaşayanların müsnedlerine karışması. Nitekim Hâfız İbn Asâkir (öl.571/1176) Tertîbü Esmâi's-Sahâbe adlı eserinde bunların tamamına dikkat çekmiş bulunmaktadır." 11

Paragrafta isabetle belirtilen birden fazla temel problemden ilki, Kuzudişli'nin yukarıda işaret edilen makalesinde Ebû Hüreyre örneği üzerinde ele alınmıştır. Ayrıca başta müksirûn olmak üzere hangi sahabiye ait kaç rivayetin ilgili sahabinin müsnedinin dişında rivayet edildiğine dair bir döküm de yine Müsned tahkikinin mukaddimesinde yer almaktadır. Bu dökümde 39 sahabinin isimleri (Tertîbü Esmâi's-Sahâbe muhakkiki Dr. Âmir Hasen sSabrî'den naklen) liste hâlinde verilmiş ve her birine ait rivayetlerin hangi farklı sahabinin müsnedinde yer aldığına şu örnekte görüldüğü şekilde atıfta bulunulmuştur:

“23. el-Fadl b. Abbâs: Kardeşi Abdullah'ın müsnedinde (1/355 ve 359) iki hadisi vardır. el-Muttalib b. Rabîa'nın müsnedinde de (4/167) bir hadisi vardır." ${ }^{12}$

Ancak bahsi geçen 39 rakamı "Müsned bünyesinde hadisleri bir bölümde derli toplu verilen ama bazı rivayetleri bu ana bölümün/müsnedin dışında yer alan başlıca isimler" şeklinde ele alınmalıdır. Zira bizim tespitlerimize göre "Müsned' de hadisleri birden fazla yerde

10 Kuzudişli, “Müsnedleri Dışında Zikredilen Sahâbîler", 69-95.

11 Ahmed b. Hanbel, el-Müsned, 1/59 (muhakkikin mukaddimesi).

12 Ahmed b. Hanbel, el-Müsned, 1/60-64 (muhakkikin mukaddimesi. Tertîbü Esmâi's-Sahâbe muhakkiki Dr. Âmir Hasen s-Sabrî̀ den naklen). 
verilen sahabiler" çerçevesinde düşünüldügüunde ve incelendiğinde ortaya çıkan rakamlar çok daha yüksek olacaktır. Şöyle ki:

Normal olan, Aşere-i Mübeşşere'den başlayan ve Ehl-i Beyt ile devam eden mezkûr sıralama içinde, her bir sahabinin rivayetlerini tek yerde "Filancanın Müsnedi" başlığı altında vermektir. Bu, ilgili sahabinin bir hadisi de olsa bin hadisi de olsa değişmemesi gereken prensiptir. Dolayısıyla Müsned'de toplam iki hadisi yer alan ve bu hadisleri farklı ciltlerde 1+1 şeklinde konumlanan isimler de dâhil olmak üzere, standart dışı olduğu tespit edilen hayli fazla yapıyla karşılaşılmış olup, bu yapılar "parçalı müsned" tanımı altında ileride detaylarıyla değerlendirmeye alınacaktır.

Bu aşamada özetle vurgulamak gerekirse, araştırmada yapılması amaçlanan, yukarıda Müsned muhakkiklerinin dikkat çektiği iki ana problemden, önce "tek bir sahabinin hadislerinin Müsned'in birden fazla yerinde ayrı ayrı verilmesi" meselesini, ardından da "tek bir hadisin ilave bir yarar olmaksızın senediyle ve metniyle tekrar edilmesi" sorununu bazı boyutlariyla irdelemektir.

\subsection{Parçalı Müsnedler}

Eser bünyesinde dağınıklığa yol açan faktörlerin başında, bir sahabinin müsnedinin birden fazla parçaya bölünerek bu parçaların birbirinden oldukça uzak sayfa veya ciltlerde konumlanmış olması gelmektedir. Bu bağlamda, aynı kitap içinde iki hatta üç farklı yerde müsnedinin parçaları bulunan isimlere rastlanabilmektedir. Sahabe tabakasında yer alıp da senedlerde adı verilmeyen ve tahkikin sonunda" ${ }^{13}$ "İsmi Verilmeyen Sahabiler: Fihrisu men Lem Yusemme mine's-Sahâbe" başlıklı bir listede toplanan mübhem raviler bir kenara bırakılırsa, eserdeki 745 müsnedin "standart olanlar" ve "parçalı olanlar" şeklinde ikiye ayrılması mümkündür.

Standart müsnedlerden kasıt, adına bir defa başlık açılıp bütün hadisleri tek bir yerde nakledilen sahabilere ait standart (Tablo-3'de: S) bölümlerdir. Bu isimlerden müsnedinde sadece bir hadis bulunanlar (Tablo-3'de: S1) olduğu gibi; müsnedi kitabın birden fazla yerine dağılmış bulunanlar da mevcuttur. Kısaca "parçalı müsned" olarak adlandıracağımız bu örnekler ise genellikle iki parçadan müteşekkildir. Müsnedi iki parça olup her bir parçasında sadece birer rivayeti yer alan isimlerin durumlarına Tablo-3'de (1+1) ifadesiyle işaret

13 Ahmed b. Hanbel, el-Müsned, 50/23-32. Mübhem ravi kavramı için bkz: Aydınlı, Hadis Istılahları Sözlü̆̆̈̈̈, 190192. 
edilmiştir. İçerikleri tablonun ardından ele alınacak olan (K1), (K2), (K3) ile de sırasıyla kısaca “Hadis sayısı 50’yi aşkın olan” (K1), “Hadis sayısı 11-50 aralığında olan” (K2) ve “Hadis sayısı 10 veya daha az olan" (K3) sahabilerin müsnedlerinin iki parçaya ayrılması kastedilmektedir. “Diğer" başlı̆̆g ise buraya kadarki ihtimallerin dışında kalan ve ikiden fazla parçaya ayrılmış öteki müsnedleri kapsamaktadır.

Temel çerçeveyi zikrettikten sonra araştırmanın geldiği noktada oluşan tabloyu sunabiliriz.

Tablo 3: Sahabi Müsnedlerinin Nihai Dağılımı

\begin{tabular}{|c|c|c|c|}
\hline Müsned Tipi & Alt Tip & Örnek Sayıs1 & Genele Oranı \\
\hline \multirow{8}{*}{$\begin{array}{c}\text { Standart } \\
\text { (499) }\end{array}$} & $S$ & 273 & $\% 37$ \\
\hline & S1 & 198 & $\% 27$ \\
\hline & $S(+1)$ & 14 & \multirow{8}{*}{$\% 9$} \\
\hline & $S(+2)$ & 8 & \\
\hline & $S(+3)$ & 2 & \\
\hline & $S(+4)$ & 2 & \\
\hline & $S(+6)$ & 1 & \\
\hline & $S(+11)$ & 1 & \\
\hline \multirow{5}{*}{$\begin{array}{c}\text { Parçalı } \\
(246)\end{array}$} & K1 & 5 & \\
\hline & $\mathrm{K} 2$ & 36 & \\
\hline & K3 & 108 & $\% 14$ \\
\hline & $1+1$ & 39 & $\% 5$ \\
\hline & Diğger & 58 & $\% 8$ \\
\hline Genel Toplam & \multicolumn{2}{|c|}{745} & - \\
\hline
\end{tabular}

Tabloda görülen sonuç, eserin sahabi sayısı itibarıyla üçte ikisini, hadis sayısında ise yaklaşık olarak beşte dördünü ifade eden bir bölümünün standart müsned yapısına sahip olduğudur. Bu kesimin rivayetleri tek bir yerde toplanmış ve 273 kişide ilgili isme ayrılan ana müsned gövdesinin dışına taşan hiçbir istisnai durum oluşmamıştır. Ana gövdenin dışına birkaç rivayetin taştığ ${ }_{1}$ ve genel tabloyu bozmadığı durumlarla birlikte 300 küsur müsned bu durumda olup, 200'e yakın müsned ise tek hadisten müteşekkildir ve doğal olarak yine tek noktada konumlanmıştır. 
"Parçalı" başlığı altında ele alınan beş alt tipten ilk dördü, iki parça hâlinde sunulan müsnedleri ifade etmektedir. Burada 100'ü aşkın örnekte “Hadis sayısı 10 veya daha az olan sahabilerin müsnedlerinin iki parçaya ayrılması" (K3) söz konusudur. (1+1) olarak ifade edilen kategoride ise kırka yakın örnek yer almakta olup, bunların büyük kısmında sahabiye ait ikinci parça/rivayet ilkinin sened ve metin olarak birebir tekrarı konumundadır.

"Diğer" başlığı ise üç veya daha fazla parçaya ayrılan müsnedleri ifade etmektedir. 58 örnekten ikisi hadis sayısı 50'yi aşkın olan sahabilerden müsnedi üç parçaya ayrılanlara; dokuzu hadis sayısı 11-50 aralığındaki sahabilerden aynı durumda olanlara; 39 tanesi ise hadis sayısı 10 veya daha az olan sahabilerden benzer konumdakilere aittir. 11-50 aralığından 2 kişi (Ebü'l-Hakem b. Süfyân ve Ka'b b. Mürra es-Sülemî) ve 1-10 aralığından 5 kişinin (Abdullah b. Havâle el-Ezdî, Dirâr ibnü'l-Ezver, Kurra b. İyâs el-Müzenî, Sahr el-Ğâmidî ve Ümmü Büceyd) müsnedleri dört parça; yine hadis sayısı 11-50 aralığında olan bir sahabinin (Sehl b. Ebî Hasme) müsnedi ise altı parça hâlinde sunulmuştur. Bütün bu sayısal tespitlerin esas alınan tahkikli müsned baskısının fihristlerine dayanılarak yapıldığı vurgulanmalı, metin içinde yapılan detaylı incelemelerde fihristten farklı olduğu tespit edilen durumlara rastlandığının da altı çizilmelidir.

Yapılan mukayeselerde bu parçaların büyük bölümünün birbirinin hem sened hem metin bakımından aynen tekrarı olmadığı, fakat Müsned'in genelinde olduğu gibi buralarda da hatırı sayılır miktarda muhteva tekrarının bulunduğu tespit edilmiştir. Yine bu parçaların hadis sayısı bakımından yüksek rakamlara ulaşmadığının da altı çizilmelidir. Bir fikir vermesi açısından, tespit edilen "parçalı müsned" örnekleri üç kategori hâlinde, sahabi isimleri, cilt, sayfa ve hadis numaraları ile hadis sayılarını içeren tablolar eşliğinde aşağıda sunulacaktır.

\subsubsection{Kategori-1: Rivayet Sayısı 50'nin Üzerinde Olanlar}

50 rakamı -yapılan incelemelere dayanarak- sınır kabul edildiğinde, müsnedi birden fazla yerde parçalı olarak sunulan sahabiler arasında toplam rivayet sayısı söz konusu barajı aşan birden fazla isim olmakla birlikte, yüzün üzerinde rivayeti olan tek sahabi Ebü'dDerdâ'dır. Diğer örneklerden bazılarıyla birlikte şöyle bir tablo oluşmaktadır. 
Tablo 4: Kategori-1'e Ait Parçalı Müsned Örnekleri

\begin{tabular}{|c|c|c|c|c|}
\hline Sıra No & Sahabi Adı & Hadis No & Cilt ve Sayfa & $\begin{array}{c}\text { Toplam Hadis } \\
\text { Sayısı }\end{array}$ \\
\hline 1 & Zeyd b. Hâlid el- & $17029-17062 ;$ & $28 / 255-294 ;$ & $33+19=52$ \\
& Cühenî & $21673-21691$ & $36 / 7-21$ & \\
\hline 2 & Ebû Mes' ûd el-Bedrî & $17063-17110 ;$ & $28 / 295-333 ;$ & $48+22=70$ \\
& & $22339-22361$ & $37 / 30-44$ & \\
\hline 3 & Adiy b. Hâtim & $18244-18274 ;$ & $30 / 177-209 ;$ & $31+26=57$ \\
& & $19369-19394$ & $32 / 112-137$ & \\
\hline 4 & Abdullah b. Ebî Evfâ & $19102-19151 ;$ & $31 / 449-488 ;$ & $50+23=73$ \\
& & $19395-19417$ & $32 / 138-159$ & \\
\hline 5 & Ebü'd-Derdâ & $21692-21741$ & $36 / 22-67$ & $50+80=130$ \\
& & $27478-27557$ & $45 / 472-538$ & \\
\hline
\end{tabular}

Sahabilerin alfabetik olarak veya rivayet ettikleri hadis sayısına göre değil, eser içinde müsnedlerine ilk yer veriliş sırasına göre listelendiği bu tablo, aşağıda verilecek Kategori-2 ve 3'e ait tablolarla yan yana incelenebilir. Bu yapıldığında, parçalı müsnedlerin bir kısmında aynı sahabiye ait müsnedin iki ayrı parçası aynı veya ardışık ciltlerde tasnif edilmiş iken, büyük bölümünde ise birbirinden oldukça bağımsız noktalarda konumlandığı görülecektir. Nitekim iki parçanın arasına on cildi aşkın bir mesafenin girdiği örnekler her üç tabloda da görülmektedir ki, bunun bilgisayar teknolojisinin olmadığı dönemler için eserin kullanımını oldukça zorlaştıran ve dolayısıyla tasnifin başında ideal olarak planlanmamış bir husus olduğu rahatlıkla ifade edilebilir. Ayrıca aynı veya ardışık ciltlerde yer alan parçalı müsnedlere dair örneklerin çoğunluğunun hanım sahabilere ait olduğuna ve bu durumun hanım sahabilere ait müsnedlerin eserin sonunda bir arada verilmesinden kaynaklanmış olabileceğine de dikkat çekilmelidir.

\subsubsection{Kategori-2: Rivayet Sayısı 10-50 Aralığında Olanlar}

Parçalı müsnedlerin önemli bir bölümünde, sahabinin toplam rivayet sayısı 10-50 aralığında ve müsnedi iki parçaya ayrılmış durumdadır. Tespit edilen bazı örnekler Tablo-5'te sunulmuştur. 
Tablo 5: Kategori-2'ye Ait Parçalı Müsned Örnekleri

\begin{tabular}{|c|c|c|c|c|}
\hline Sira No & Sahabi Adı & Hadis No & Cilt ve Sayfa & $\begin{array}{c}\text { Toplam Hadis } \\
\text { Sayısı }\end{array}$ \\
\hline 1 & Hakîm b. Hizâm & $\begin{array}{l}\text { 15311-15329; } \\
15573-15580\end{array}$ & $\begin{array}{c}24 / 25-45 \\
24 / 341-346\end{array}$ & $20+8=28$ \\
\hline 2 & Mâlik ibnü'l-Huveyris & $\begin{array}{l}15598-15604 ; \\
20529-20539\end{array}$ & $\begin{array}{l}\text { 24/364-370; } \\
34 / 157-163\end{array}$ & $7+11=18$ \\
\hline 3 & Târık b. Eşyem & $\begin{array}{l}\text { 15875-15882; } \\
27208-27213\end{array}$ & $\begin{array}{l}\text { 25/212-216; } \\
45 / 187-189\end{array}$ & $8+6=14$ \\
\hline 4 & Vâsile ibnü'l-Eska' & $\begin{array}{l}\text { 16004-16019; } \\
16978-16989\end{array}$ & $\begin{array}{l}\text { 25/385-400; } \\
\text { 28/186-198 }\end{array}$ & $16+12=28$ \\
\hline 5 & Ukbe ibnü'l-Hâris & $\begin{array}{l}16148-16155 ; \\
19423-19427\end{array}$ & $\begin{array}{c}26 / 70-76 \\
32 / 165-166\end{array}$ & $8+5=13$ \\
\hline 6 & Osmân b. Ebi'l-Âs & $\begin{array}{l}16268-16282 ; \\
17897-17918\end{array}$ & $\begin{array}{l}\text { 26/196-210; } \\
\text { 29/429-441 }\end{array}$ & $14+22=36$ \\
\hline 7 & Ebû Şurayh el-Huzâ'î & $\begin{array}{l}16370-16378 ; \\
27159-27165\end{array}$ & $\begin{array}{l}26 / 291-303 ; \\
45 / 136-142\end{array}$ & $9+7=16$ \\
\hline 8 & Amr ibnü'l-Âs & $\begin{array}{l}17761-17781 ; \\
17801-17827\end{array}$ & $\begin{array}{l}\text { 29/296-320; } \\
\text { 29/337-360 }\end{array}$ & $21+27=48$ \\
\hline 9 & Ammâr b. Yâsir & $\begin{array}{l}18313-18334 \\
18879-18894\end{array}$ & $\begin{array}{l}30 / 245-279 ; \\
31 / 171-189\end{array}$ & $22+15=37$ \\
\hline 10 & $\begin{array}{l}\text { Suheyb b. Sinân er- } \\
\text { Rûmî }\end{array}$ & $\begin{array}{l}\text { 18931-18942; } \\
\text { 23924-23931 }\end{array}$ & $\begin{array}{l}31 / 259-272 ; \\
39 / 347-354\end{array}$ & $12+8=20$ \\
\hline 11 & $\begin{array}{c}\text { Ümmü 'Attyye el- } \\
\text { Ensâriyye }\end{array}$ & $\begin{array}{l}\text { 20789-20801; } \\
\text { 27297-27309 }\end{array}$ & $\begin{array}{l}34 / 384-397 ; \\
45 / 280-289\end{array}$ & $13+13=26$ \\
\hline 12 & Habbâb ibnü'l-Eret & $\begin{array}{l}21052-21079 ; \\
27214-27219\end{array}$ & $\begin{array}{l}34 / 530-556 ; \\
45 / 190-193\end{array}$ & $28+6=34$ \\
\hline 13 & Ebû Râfi' & $\begin{array}{l}\text { 23855-23878; } \\
27180-27198\end{array}$ & $\begin{array}{l}39 / 278-305 \\
45 / 161-176\end{array}$ & $24+19=43$ \\
\hline 14 & Ümmü Habîbe & $\begin{array}{l}26759-26785 ; \\
27394-27412\end{array}$ & $\begin{array}{l}44 / 342-369 ; \\
45 / 389-402\end{array}$ & $27+18=45$ \\
\hline 15 & Ümmü Hânî & $\begin{array}{c}\text { 26887-26911; } \\
27379-27393\end{array}$ & $\begin{array}{l}\text { 44/455-480; } \\
45 / 378-388\end{array}$ & $25+14=39$ \\
\hline
\end{tabular}




\subsubsection{Kategori-3: Rivayet Sayısı 10 veya Daha Az Olanlar}

Yapılan incelemede, toplam rivayet sayısı 10 veya daha az olmasına rağmen hadisleri iki parça hâlinde tasnif edilmiş çok sayıda örnek de tespit edilmiştir.

Tablo 6: Kategori-3'e Ait Parçalı Müsned Örnekleri

\begin{tabular}{|c|c|c|c|c|}
\hline Sira No & Sahabi Ad1 & Hadis No & Cilt ve Sayfa & $\begin{array}{c}\text { Toplam Hadis } \\
\text { Sayısı }\end{array}$ \\
\hline 1 & Muaykîb & $\begin{array}{c}15509-15511 ; \\
23609-23612\end{array}$ & $\begin{array}{c}24 / 268-270 \\
39 / 23-24\end{array}$ & $3+4=7$ \\
\hline 2 & Mücâşi' b. Mes'ûd & $\begin{array}{c}\text { 15847-15851; } \\
20684\end{array}$ & $\begin{array}{c}25 / 176-179 \\
34 / 286\end{array}$ & $5+1=6$ \\
\hline 3 & Zeyneb es-Sekafiyye & $\begin{array}{l}16082-16084 ; \\
27046-27050\end{array}$ & $\begin{array}{l}\text { 25/490-492; } \\
44 / 595-602\end{array}$ & $3+5=8$ \\
\hline 4 & ‘Itbân b. Mâlik & $\begin{array}{l}16479-16484 ; \\
23770-23773\end{array}$ & $\begin{array}{c}\text { 27/7-14; } \\
39 / 187-190\end{array}$ & $6+4=10$ \\
\hline 5 & ‘Umâra b. Ruveybe & $\begin{array}{l}\text { 17219-17224; } \\
18297-18299\end{array}$ & $\begin{array}{l}\text { 28/455-459; } \\
30 / 230-232\end{array}$ & $6+3=9$ \\
\hline 6 & Süleyman b. Surad & $\begin{array}{l}18308-18312 ; \\
27205-27207\end{array}$ & $\begin{array}{l}30 / 240-244 ; \\
45 / 183-186\end{array}$ & $5+3=8$ \\
\hline 7 & Zeyneb bint Cahş & $\begin{array}{l}\text { 26751-26754; } \\
\text { 27413-27416 }\end{array}$ & $\begin{array}{l}\text { 44/332-336; } \\
45 / 402-406\end{array}$ & $4+4=8$ \\
\hline 8 & $\begin{array}{c}\text { Cüveyriye bintü'l- } \\
\text { Hâris }\end{array}$ & $\begin{array}{l}26755-26758 ; \\
27420-27425\end{array}$ & $\begin{array}{l}44 / 336-341 ; \\
45 / 410-413\end{array}$ & $4+6=10$ \\
\hline 9 & $\begin{array}{l}\text { Ümmü Harâm bint } \\
\text { Milhân }\end{array}$ & $\begin{array}{l}\text { 27032-27033; } \\
\text { 27377-27378 }\end{array}$ & $\begin{array}{l}\text { 44/581-583; } \\
45 / 376-377\end{array}$ & $2+2=4$ \\
\hline 10 & Havle bint Hakîm & $\begin{array}{l}27120-27123 ; \\
27310-27315\end{array}$ & $\begin{array}{c}45 / 87-91 ; \\
45 / 290-295\end{array}$ & $4+6=10$ \\
\hline
\end{tabular}

Yukarıdaki her üç tabloda da (Tablo-4-6) bir sahabi için yer verilen ikinci cilt/sayfa atfındaki rivayetlerin büyük oranda ilk atıftakilerin tekrarından oluştuğunu öngörmek zor değildir. Sözgelimi Itbân b. Mâlik'in 27/7-14 (16479-16484) ve 39/187-190'da (23770-23773) toplam on rivayeti yer almakta olup, 39. ciltteki ikinci parçada bulunan dört hadisin tamamı ilk parçada geçenlerin tekrarlarıdır. (23770-23772 numaralı üç ardışık rivayet, Itbân b. Mâlik 
müsnedinin ilk parçasında yer alan ve Allah Resûlü'nün (sav) gelip sahabinin evinde namaz kıldığını anlatan 16481-16484 numaralı rivayetlerin tekrarıdır. 23773 numaralı rivayet ise olayın duha namazı çerçevesinde nakledilmiş daha kısa versiyonunu içeren 16479 numaralı rivayet ile benzeşmektedir.) Zira Ahmed b. Hanbel genel bir uygulama olarak bir sahabinin meşhur rivayetlerine o sahabinin müsnedinin giriş bölümünde yer vermekte ve bu prensip parçalı müsnedlerde ilk parça üzerinde cereyan etmektedir. Dolayısıyla buradaki durumun bir sonraki başlıkta ele alınacak olan mükerrerler meselesini besleyen bir yönünün olduğu da aşikârdır.

\section{Mükerrer Rivayetler}

Mükerrer rivayetlere ayrılan bu başlık altında öncelikle tarafımızdan yapılmış olan Müsned seçkisi çalışmasının konuyu ilgilendiren verileri mercek altına alınacaktır. Ardından (1+1) düzenine sahip parçalı müsnedlerin sened ve metinlerine dair detaylı bir inceleme yapilacaktır.

\subsection{Müsned'deki Tekrar Oranları}

Mülteka'l-Ashâbi'l-Emced fì İntikâi Mesânîdi Ahmed adlı söz konusu seçki çalışmasında Ahmed b. Hanbel' in Müsned'i genel bir okuma ve taramaya tabi tutularak içinden, sahih, kavlî ve merfû olma özelliklerinin üçünü birden taşıyan hadisler tespit edilmiştir. Ebû Hüreyre Müsnedi'nden alınan hadis sayısının 200 ile sınırlandırıldığı ve neticede 146 sahabiden nakledilen 1010 rivayetin yine müsned tarzında bir araya getirildiği bu çalışmada mükerrer hadis yer almamaktadir.

Her bir hadisin müsned içindeki birebir tekrarları titizlikle tespit ve kaydedildiği için, Mültekấ'da oluşan birikimin buradaki incelemeye katkı sağlayacağı düşünülmüştür. Sıhhat bakımından hasen ve zayıf; mahiyeti ve kaynağı açısından da fiilî/takrîrî ve mevkûf/maktû içerikler dışarıda kalmak kaydıyla, eldeki sonuçlar şöyledir.

Tablo 7: “Sahih, Kavli ve Merfû" Rivayetlerin Tekrarlanma Oranı

\begin{tabular}{|c|c|c|c|}
\hline Bölüm & Alınan Hadis Sayısı & $\begin{array}{c}\text { Alınan Hadislerin } \\
\text { Toplam Tekrar Sayısı }\end{array}$ & $\begin{array}{c}\text { Hadis Başına } \\
\text { Ortalama Tekrar }\end{array}$ \\
\hline Aşere-i Mübeşşere & 50 & 114 & 2.28 \\
\hline Ebû Hüreyre & 200 & 566 & 2.83 \\
\hline 80 Hadis Alınanlar & 240 & 685 & 2.85 \\
\hline
\end{tabular}




\begin{tabular}{|c|c|c|c|}
\hline 40 Hadis Alınanlar & 160 & 322 & 2.01 \\
\hline 20 Hadis Alınanlar & 60 & 95 & 1.58 \\
\hline 10 Hadis Alınanlar & 70 & 132 & 1.88 \\
\hline 5 Hadis Alınanlar & 75 & 141 & 1.88 \\
\hline 3 Hadis Alınanlar & 42 & 91 & 2.16 \\
\hline 2 Hadis Alınanlar & 48 & 79 & 1.64 \\
\hline 1 Hadis Alınanlar & 65 & 51 & 0.78 \\
\hline+ & 1010 & 2276 & 2.25 \\
\hline
\end{tabular}

Müksirûnda üçe yaklaşan, az sayıda hadisi olan sahabilerde ise birin altına düşen ortalama tekrar sayısı, genel bir hesapla Müsned'in üçte ikisinden fazlasının mükerrer rivayetlerden oluştuğunu ortaya koymaktadır ki, daha önce yapılan başka araştırmalarda da bu duruma dikkat çekilmiştir ${ }^{14}$. Dolayısıyla tekrarların hangi mahiyette olduğu ve standart yahut parçalı müsnedlerle arasında ne tür bir bağlantı bulunduğu burada incelenmeye değer addedilmiştir.

\subsection{Parçalı Müsnedler ve Tekrar Olgusu: (1+1) Yapılar Örneği}

Kendisinden toplamda sadece iki hadis rivayet edilen ve bu hadislerin ardişık olarak verilmediği, çoğu zaman da bağımsız ciltlerde yer aldığı örneklere Ahmed b. Hanbel'in Müsned'inde 39 sahabi özelinde rastlandığına Tablo-3'te dikkat çekilmişti. Bu örneklerin üçte birine tekabül eden 13 sahabinin parçalı müsnedlerinden oluşan bir örneklem üzerinde yoğunlaşılmış ve ikinci parçada rivayet edilen hadisin ilk parçada nakledilenle ne ölçüde benzeştiği ölçülmeye çalışılmıştır.

Tablo 8: (1+1) Düzenindeki Parçalı Müsned Örnekleri

\begin{tabular}{|c|c|c|c|c|c|c|c|}
\hline $\begin{array}{c}\text { Sıra } \\
\text { No }\end{array}$ & Sahabi Adı & $\begin{array}{c}\text { Hadis } \\
\text { No }\end{array}$ & Cilt/Sayfa & Konu & $\begin{array}{c}\text { İsnad } \\
\text { Uyumu }\end{array}$ & $\begin{array}{c}\text { Metin } \\
\text { Uyumu }\end{array}$ & $\begin{array}{c}\text { Sıhhat } \\
\text { Hükmü }\end{array}$ \\
\hline 1 & $\begin{array}{c}\text { İyâs b. Abd } \\
\text { el-Müzenî }\end{array}$ & $\begin{array}{c}15444, \\
17236\end{array}$ & $\begin{array}{c}24 / 178- \\
179, \\
28 / 472\end{array}$ & Su satışı & T2 & Çok Yakın & Sahih \\
\hline 2 & $\begin{array}{c}\text { Uveymir b. } \\
\text { Eşgar }\end{array}$ & $\begin{array}{c}15762, \\
19001\end{array}$ & $\begin{array}{c}25 / 41-42, \\
31 / 339\end{array}$ & $\begin{array}{c}\text { Kurban } \\
\text { kesimi }\end{array}$ & Aynı & Çok Yakın & $\begin{array}{c}\text { Sahih li } \\
\text { Gayrih }\end{array}$ \\
\hline
\end{tabular}

14 Kuzudişli, “Müsnedleri Dışında Zikredilen Sahâbîler", 69. 


\begin{tabular}{|c|c|c|c|c|c|c|c|}
\hline 3 & $\begin{array}{c}\text { Ebû Sa'îd b. } \\
\text { Ebî Fedâle }\end{array}$ & $\begin{array}{l}15838 \\
17888\end{array}$ & $\begin{array}{c}25 / 161- \\
162 \\
29 / 418\end{array}$ & Şirk & Aynı & Aynı & $\begin{array}{l}\text { Sahih li } \\
\text { Ğayrih- } \\
\text { Hasen }\end{array}$ \\
\hline 4 & $\begin{array}{l}\text { Sa'îd b. } \\
\text { Hureys }\end{array}$ & $\begin{array}{l}15842 \\
18739\end{array}$ & $\begin{array}{c}25 / 166- \\
167 \\
31 / 36\end{array}$ & $\begin{array}{l}\text { Ev ve arazi } \\
\text { satış1 }\end{array}$ & T1, T3 & Çok Yakın & $\begin{array}{c}\text { Hasen- } \\
\text { Zayıf }\end{array}$ \\
\hline 5 & $\begin{array}{l}\text { Abdullah b. } \\
\text { Sâbit }\end{array}$ & $\begin{array}{l}15864 \\
18335\end{array}$ & $\begin{array}{c}25 / 198- \\
199 \\
30 / 280\end{array}$ & $\begin{array}{c}\text { Peygambere } \\
\text { İtaat }\end{array}$ & Aynı & Aynı & Zayif \\
\hline 6 & $\begin{array}{c}\text { Abdullah b. } \\
\text { Erkam }\end{array}$ & $\begin{array}{l}15959 \\
16400\end{array}$ & $\begin{array}{c}25 / 317- \\
320 \\
26 / 325-326\end{array}$ & $\begin{array}{c}\text { Tuvalet } \\
\text { ihtiyacı } \\
\text { varken } \\
\text { namaz } \\
\text { kılmamak }\end{array}$ & Aynı & Aynı & Sahih \\
\hline 7 & $\begin{array}{c}\text { Şeddâd } \\
\text { ibnü'l-Hâd }\end{array}$ & $\begin{array}{l}16033 \\
27647\end{array}$ & $\begin{array}{c}25 / 419- \\
420 \\
45 / 613-614\end{array}$ & $\begin{array}{l}\text { Sirtında } \\
\text { çocukla } \\
\text { namaz } \\
\text { kılmak }\end{array}$ & Aynı & Aynı & Sahih \\
\hline 8 & Ebû Şuayb & $\begin{array}{l}17085, \\
17093\end{array}$ & $\begin{array}{c}28 / 315 \text { ve } \\
321\end{array}$ & $\begin{array}{c}\text { Davete } \\
\text { katılma } \\
\text { adab1 }\end{array}$ & Farklı & Çok Yakın & Sahih \\
\hline 9 & $\begin{array}{c}\text { Ebû Sa'îd b. } \\
\text { Zeyd }\end{array}$ & $\begin{array}{l}17504, \\
19040\end{array}$ & $\begin{array}{c}29 / 48-49 \\
31 / 387\end{array}$ & $\begin{array}{l}\text { Cenaze } \\
\text { geçerken } \\
\text { ayağa } \\
\text { kalkmak }\end{array}$ & Aynı & Aynı & $\begin{array}{l}\text { Sahih- } \\
\text { Zayıf }\end{array}$ \\
\hline 10 & $\begin{array}{l}\text { Abdullah b. } \\
\text { Ebî Habîbe }\end{array}$ & $\begin{array}{l}17944, \\
18951\end{array}$ & $\begin{array}{c}29 / 463- \\
464 \\
31 / 281\end{array}$ & $\begin{array}{l}\text { Nalınla } \\
\text { namaz } \\
\text { kılmak }\end{array}$ & $\mathrm{T} 1$ & Çok Yakın & Zayıf \\
\hline 11 & $\begin{array}{l}\text { Seleme b. } \\
\text { Nu'aym }\end{array}$ & $\begin{array}{l}18284 \\
22464\end{array}$ & $\begin{array}{l}30 / 217 \\
37 / 130\end{array}$ & $\begin{array}{c}\text { Şirk } \\
\text { koşmayanın } \\
\text { cennete } \\
\text { girmesi }\end{array}$ & $\mathrm{T} 1$ & Aynı & Sahih \\
\hline 12 & $\begin{array}{l}\text { el-Haşhâş } \\
\text { el-Anberî }\end{array}$ & $\begin{array}{l}19031 \\
20769\end{array}$ & $\begin{array}{c}31 / 376 \\
34 / 368-369\end{array}$ & $\begin{array}{l}\text { Suçun } \\
\text { şahsiliği }\end{array}$ & T3 & Aynı & Sahih \\
\hline 13 & $\begin{array}{l}\text { Selmâ bint } \\
\text { Kays }\end{array}$ & $\begin{array}{l}27133 \\
27375\end{array}$ & $\begin{array}{c}45 / 103-105 \\
\text { ve } 374\end{array}$ & $\begin{array}{c}\text { Eşi } \\
\text { aldatmamak }\end{array}$ & $\mathrm{T} 1$ & $\begin{array}{l}\text { Çok } \\
\text { Yakın }\end{array}$ & Zayıf \\
\hline
\end{tabular}

Son sütunda verilen sıhhat hükümleri, ilgili hadis hakkında tahkikte öngörülen hükümler olup, iki sıhhat hükmü birden kullanılmışsa, ilki hadisin durumunu, ikincisi ise söz 
konusu senedin durumunu belirtmektedir. Sözgelimi "Hasen-Zayıf" hükmü, her iki senedi birden kapsayacak şekilde "Hasen bir hadistir; ama bu isnad zayıftır" anlamına gelmektedir. Detayları Tablo-8'de sunulan incelemede ulaşılan sonuçlar, 13 örnekten beşinde $(3,5$, 6, 7 ve 9. maddeler) parçalı müsnedin her iki bölümünde nakledilen birer hadisin sened ve metin bakımından birbirinin aynen tekrarı olduğunu göstermiştir. Kalan sekiz örneğin birinde sadece sened aynı, üçünde senedde sadece musannifin şeyhi farklı (T1), birinde musannifin şeyhi ve onun şeyhi farklı (T2), ikisinde ise sadece bir ravi ziyade veya noksandır (T3). Senedi sahabi ravi dışında tamamen farklı olan Ebû Şuayb hadisleri bu noktada tek istisnayı oluşturmaktadır.

Metin bakımından ise söz konusu sekiz örnekten ikisinde rivayet içeriklerinin aynı, altısında birbirine çok yakın olduğu görülmüştür. Metin bağlamında kullanılan "çok yakın" nitelemesiyle "takdim-tehir gibi ufak farklılıklar barındıran ve tek çeviriyle gelebilecek ölçüde birbirine yakın lafızlar" kastedilmektedir.

Bütün bunlara bakılarak denilebilir ki, (1+1) yapılarda, parçalı müsnedin her iki yakasındaki rivayetler gerek sened, gerek metin, gerekse sıhhat hükmü bakımından çok büyük oranda benzeşmekte ve birbirini tekrar etmektedir. Tablo-7 ile yan yana düşünüldüğünde de, hadis sayısı daha az olan sahabilerin rivayetlerine ait mükerrerlerde sened ve metin bakımından aynen tekrar edilme oranının daha yüksek olduğu, (1+1) yapıların ise bu önermenin en ileri örneği sayılabileceği tespit edilebilecektir.

\section{Sonuç}

Ahmed b. Hanbel'in dönemin siyasi şartlarından dolayı eserini yazdıktan sonra düzenli olarak okutamadığı bilinmektedir. Mihne ortamında temel önceliğin eldeki bilimsel birikimi sonraki nesillere aktarmak olduğu, mucem ve müsned tarzı pek çok eserin konu veya sıhhat ayrımına odaklanmadan, rivayet hakkı alınmış hadisleri kayıt altına alıp yok olmaktan korumayı amaçladığı da bilinen bir diğer husustur. Dolayısıyla son beş cildi fihristten oluşan 50 ciltlik baskısı esas alınarak incelenen Müsned' in -ilk yarısına tekabül eden- 23 cildinin belirli bir iç düzene sahip olduğu, ikinci yarısında ise büyük bir düzensizliğin göze çarptığ1 söylenebilir. Müellifin ana ravisi konumundaki oğlu Abdullah'ın esere yaptığı ziyadelerin mahiyeti de mevcut metnin düzensizliğini ortadan kaldırmamış ve tekrar oranını bilakis artıran bir unsur hâlini almıştır. 
Nitekim Müsned'in iç düzeni hakkında yapılan bu araştırma, daha önceki araştırmalarda da kısmen belirtildiği gibi, eserin önemli tasnif sorunları içerdiğini teyit etmiştir. Tekrarına burada gerek duyulmayan birden fazla ana problem içerisinden "parçalı müsnedler problemi" olarak özetlenebilecek bir nokta seçilmiş ve "bir sahabinin müsnedinin birden fazla parçaya bölünerek bu parçaların birbirinden oldukça uzak sayfa veya ciltlerde konumlanmış olması" şeklinde yapılan bir tanımdan hareket edilerek konu bu çerçevede ele alınmaya çalışılmıştır. Bu bağlamda farklı kategoriler hâlinde ele alınan müsned tiplerinin tablo eşliğinde tahlili ilginç sonuçlar ortaya çıkarmıştır.

Çalışmada, ismi net olarak verilmeden rivayeti zikredilen ve tamamına yakınından tek hadis rivayet edilen mübhem raviler bir kenara birakılarak, eserdeki 745 müsned "standart olanlar" ve "parçalı olanlar" şeklinde ikiye ayrılmıştır. Ulaşılan genel sonuç, eserin sahabi sayısı itibarıyla üçte ikisini, hadis sayısında ise yaklaşık olarak beşte dördünü ifade eden bir bölümünün standart müsned yapısına sahip olduğudur. "Parçalı olanlar" başlığı altında ele alınan müsnedler arasında yer alan 100'ü aşkın örnekte “Hadis sayısı 10 veya daha az olan sahabilerin müsnedlerinin iki parçaya ayrılması" söz konusudur. Sadece iki rivayeti olan isimlerin müsnedlerinin bölünmesiyle meydana gelen ve (1+1) olarak ifade edilen kategoride ise kırka yakın örnek yer almakta olup, bunların büyük kısmında sahabiye ait ikinci parça/rivayet ilkinin sened ve metin olarak birebir tekrarı konumundadır.

Müsned'de tekrar oranlarının sahabiye ait rivayet sayısı arttıkça yükseldiği, aksi hâlde ise azaldığ1 tespit edilmiştir. İki hadisi olup (1+1) düzeninde bölünmüş olan örnekler özelindeki inceleme ise bu rivayetlerin "az tekrarın metinde değişim ihtimalini azalttı̆̆ ${ }_{1}$ ” sonucunu ortaya koyduğunu göstermiştir. Mamafih standart müsnedlerle parçalı müsnedlerin tekrarlarına ait kapsamlı bir örneklem grubunun oluşturulması ve sened ile metin bakımından mukayese edilmesi de bu noktada faydalı tespitlere kaynaklık edebilecektir. 


\section{Kaynakça}

Ahmed b. Hanbel, Ebû Abdullah. el-Müsned. Beyrut: Müessesetü'r-Risâle, 1999.

Ak, Hayati. “Türkiye'de Müsnedler Üzerine Yapılan Çalışmalarla İlgili Bibliyografik Bir İnceleme". Rumeli İslâm Araştırmaları Dergisi 1/2 (2018), 66-80.

Aydınlı, Abdullah. Hadis Istılahları Sözlüğü. İstanbul: İFAV, 2009.

Cevherî, Ebû Nasr İsmail b. Hammâd. es-Sihâh. Kahire: Dâru'l-Hadîs, 2009.

İbn Kesîr, Ebü'l-Fidâ İsmail. İhtisâru Ulûmi'l-Hadîs. Beyrut: Dâru'l-Kütübi'l-İlmiyye, 1989.

İbn Manzûr, Cemâlüddîn Muhammed b. Mükerrem. Lisânü'l-Arab. Riyad: Vizâratü'ş-Şüûni'lİslâmiyye, ts.

İbnü'l-Cezerî, Şemsüddin. el-Mas'adü'l-Ahmed fî Hatmi Müsnedi'l-İmâm Ahmed. Kahire: Dâru'lHadîs, 1995.

İbnü's-Salâh, Ebû Amr Ömer b. Abdurrahmân. Ulûmü'l-Hadîs. Beyrut: Dâru'l-Fikr, 1986.

Kandemir, Yaşar. "el-Müsned". Türkiye Diyanet Vakfı İslâm Ansiklopedisi. 32/104-105. İstanbul: TDV Yayınları, 2006.

Kaya, Ali. "Mihne Hadisesi ve Hadis İlmine Etkileri Bakımından Mihne'nin Sonuçları". Cumhuriyet Üniversitesi İlâhiyat Fakültesi Dergisi 1/19 (2015), 7-32.

Kuzudişli, Bekir. "Müsnedleri Dışında Zikredilen Sahâbîler Bağlamında Ahmed b. Hanbel'in Müsned'i -Ebû Hüreyre Örneği-". Hadis Tetkikleri Dergisi 8/2 (2010), 69-95.

Medînî, Ebû Musa. Hasâisu'l-Müsned. Kahire: Dâru'l-Hadîs, 1995.

Naim, Ahmed. Sahîh-i Buhârî Muhtasarı Tecrîd-i Sarîh Tercemesi. Ankara: Başbakanlık Basımevi, 1976.

Suyûtî, Celâlüddîn Abdurrahmân b. Ebî Bekr. Tedrîbü'r-Râvî fî Şerhi Takrîbi'n-Nevâvî. Beyrut: Dâru'l-Kitâbi'l-Arabî, 1993.

Uğur, Mücteba. Ansiklopedik Hadis Terimleri Sözlüğ̈̈. Ankara: TDV Yayınları, 1992.

Ürkmez, Ahmed. Mülteka'l-Ashâbi'l-Emced fì İntikâi Mesânîdi Ahmed. Ankara: Diyanet İşleri Başkanlığı Yayınları, 2021.

Yücesoy, Hayrettin. “Mihne”. Türkiye Diyanet Vakfi İslâm Ansiklopedisi. 30/26-28, 2006. 